\title{
TURNING TRAVELOGUE READERS INTO TOURISTS: REPRESENTATIONS OF TOURISM DESTINATIONS THROUGH LINGUISTIC FEATURES
}

\author{
Jasna Potočnik Topler \\ University of Maribor. Eslovenia
}

\begin{abstract}
This article is focused on the language of tourism as a means of economic potential. Language in tourism, especially language of promotional texts, motivates and attracts tourists to visit a certain destination, and, consequently, makes profits. In its introductory part, the article offers a short theoretical insight into the functions of tourism discourse and, further on, Rick Steves' website texts (travelogues) about European destinations are examined through discourse analysis, more precisely linguistic analysis involving analysis of syntax, semantics, and pragmatics. The results confirming the importance of lexical choices in tourism discourse are presented and discussed at the end of the article. Steves' travelogues aim to turn potential tourists into actual tourists by employing language, rich in stylistic devices and lexical imagery. The texts convince the potential tourists actually to buy the tourism services and products promoted in the texts. Thus, Steves' texts are examples of positive branding which aim to attract business. The research is orginial in the sense that it is concentrated on linguistic analysis of persuasive features based on discursive theories.
\end{abstract}

Keywords: tourism; language; lexical choices; American travelogues; branding; English.

\section{Convertir a los lectores de Travelogue en turistas: representaciones de los destinos turísticos a través de las características lingüísticas}

\section{RESUMEN}

Este artículo se centra en el lenguaje del turismo como un medio de potencial económico. Lenguaje en el turismo, especialmente el lenguaje de los textos promocionales, motiva y atrae a turistas para visitar un destino y, en consecuencia, hace ganancias. En su parte introductoria,

Fecha de recepción: 2 de enero de 2017.

Fecha de aceptación: 11 de octubre de 2017.

Faculty of Tourism. Cesta prvih borcev 36.8250 Brežice (ESLOVENIA).E-mail: jasna.potocnik1@um.si 
el artículo ofrece una visión teórica breve de las funciones del discurso del turismo. Más adelante, textos (guías de viaje) del sitio web de Rick Steves sobre destinos europeos se examinan a través del análisis del discurso, más precisamente análisis lingüístico abarcando análisis de sintaxis, semántica y pragmática. Los resultados confirman la importancia de elecciones léxicas en el discurso del turismo. Se presentan y discuten al final del artículo. Los guías de viaje de Steves tienen como objetivo convertir a turistas potenciales en turistas reales a través del empleo del lenguaje que es rico en recursos estilísticos e imágenes léxicas. Los textos convencen a los turistas potenciales para comprar los servicios turísticos y productos promovidos en los textos. Así, los textos de Steves son ejemplos del branding positivo con el objetivo de atraer negocios. La investigación es original en el sentido de que se concentra en el análisis lingüístico de características persuasivas basadas en las teorías discursivas.

Palabras clave: turismo; lenguaje; elecciones léxicas; guía de viaje estadounidenses; branding; inglés.

\section{INTRODUCTION}

Tourism is a cultural experience (Bryce, MacLaren and O'Gorman, 2013), and language is an inseparable part of it, therefore, tourism is also a linguistic experience. In addition, linguistic choices are viewed as fundamental in the construction of the tourism discourse, which is significant in the branding of destinations. In the last decade, the term tourism discourse has been established successfully in tourism and linguistic studies (Calvi, 2000; Jaworski and Pritchard, 2005; Thurlow and Jaworski, 2010), also as a means of exploring "tourism reflexivity" (Urry, 2002: 142) and representation of the tourism world in meaningful ways. This has happened because, according to Swales (1990: 24-27), tourism meets the several conditions for the constitution of a discourse community. Among the conditions are that the use of languages in tourism performs certain functions and follows certain grammatical, lexical and textual rules and requirements. Consequently, professionals in the fields of tourism have also become more aware of the fact that, in tourism, which is the largest industry in the world (Dielemans, 2008: 13), communication and discourse are crucial concepts, significant for the positioning of people and destinations. What is more, the language of tourism is not only considered a specialised discourse, but also a means of making profits. The latter supports Bourdieu's (1991: 67) theory of profits, which states that communication or, according to Bourdieu (1991: 67), "linguistic exchange" is also "an economic exchange which is established within a particular symbolic relation of power between a producer, endowed with a certain linguistic capital, and a consumer (or a market), and which is capable of procuring a certain material or symbolic profit". Not to mention that the economic potential of language tourism is manifested in the huge number of summer courses organised (Redondo-Carretero et al., 2017: 155) practically all over the world. Also Jaworski and Thurlow (2011: 287-288) defined tourism as a "communicative business" and "a language market", in fact, the authors (2011: 289) opined that "language and languages sit at the very heart of the tourist experience, its representation and its realization, its enculturation and its enactment". Thus, tourism 
discourse is significant not only for reflecting, but also for forming reality, and for making profits. It is an area of intense semiotic and symbolic production (Jaworski and Thurlow, 2015). According to Moscardo (1999), good communication contributes many things, sustainable tourism among them. In this respect, for experts employed in the tourism industry, not only the knowledge of foreign languages is significant, but also mastering of "the currently popular global discourse" (Salazar, 2006: 240). Visitors with quality information are able to choose rewarding experiences while displaying respectful behaviour. This, in the long term, creates mindful visitors who manage their impact on the environment better. Place branding has become a widely used tool in tourism promotion (Nelson, 2014: 41-42), and it happens through languages. Thus, language as the carrier of communication, ideas, and connotations, has a significant role in the tourism industry and in the branding of particular tourism destinations. It is, in fact, the most important tool for getting the messages across. Despite the recognised importance of the language and languages in branding, according to Arfin et al. (2012: 138), "there were few researches concerned with how the language and images enhance tourist destinations". Arfin et al. (138) also emphasised that both language and images have significant functions in persuading and attracting potential tourists. In other words, both the visual and the verbal representations are important. So far, the empirical approach of most research has been mainly a content analysis of printed promotion media such as brochures, magazines, pamphlets, booklets and guidebooks, and few researches have been concerned with the analysis of electronic tourism promotion, such as websites and blogs despite their popularity (Nelson, 2014, Arfin et al. 2012). Social media and the Internet have an impact on tourism (Narangajavana et al., 2017: 60), and have become the everyday habit of communication (Luo and Zhong, 2015) and search of information. In recent years, "word of mouth has been transformed into word of mouse" (Dann and Parinelli, 2007: 12 in Francesconi, 2014: 32), and Francesconi (2014: 5), among other scholars, discusses the migration of the contemporary tourism communication to the web. Since it is obvious that the Internet has become the most important source of information which "has influenced the distribution of tourism information dramatically" (Nelson, 2014: 45), the Internet language has been chosen for the analysis of the tourism discourse and tourism language. The decision to examine texts on Rick Steves' website has been made due to the fact that his website offers a variety of promotional texts in English. On the other hand, English has been chosen for the analysis because this language currently prevails in the tourism industry and still holds the status of lingua franca.

\section{METHODOLOGY AND CORPUS}

This article is focused on promotional tourism discourse, more precisely, on tourism promotion texts because tourism promotion, as Arfin et al. (2012: 136) argued, is an essential source of information for the potential tourists, influencing people when choosing destinations to which they would like to travel. Since tourism websites are significant in communicating the destination brand to the potential tourists, further on the features of website promotional texts of Rick Steves' travelogues about European destinations will be analysed, retrieved from https://www.ricksteves.com/europe, with the assumption that linguistic choices play a significant role in tourism. 
Language is "a highly organised and encoded system which employs many devices to express, indicate, exchange messages and information, represent and so forth" (Said, 1991: 21) and understanding its role, is vital for the tourism industry (Thitthongkam and Walsh, 2010: 185) in the sense that organisations can improve the coordination skills, better operate new technologies, further develop tourist satisfaction and effective management. Therefore, it is essential to be aware of the characteristics of a tourism discourse, which is, simply put, the language in the tourism context. Nuyts (2000: xv) provides the following explanation of a discourse:

Yet in reality language operates as an integral subpart of the human behavioural repertoire, serving a quite specific function in it. Hence, in a cognitive-pragmatic view, to understand (the phenomena of) language use and the system behind it/them, it is essential to acknowledge the nature of language as a dynamic functional system serving and/ or interacting intensively with other components of the human mind, in which linguistics is but one player, albeit a potentially important one, if it accepts the rules of the game.

Discourse can be defined as "the spoken, signed or written language used by people to communicate and interact in natural settings" (Cumming et al., 2011: 8). Cumming et al. (2011) also point out the awareness of the significance of context, which has led to increasing interest in the nature of context. As mentioned, besides special functions, the language of tourism has special features, including specific syntax, vocabulary, and grammar. It has its own discourse, which could be defined as "a group of statements which provide a language for talking about /.../ a particular topic at a particular historical moment" (Hall, 1997: 44). The following empirical linguistic analysis, based on MAK Halliday's (2004) discourse analysis, which involves the linguistic analysis of syntax, semantics, and pragmatics, will reveal which linguistic characteristics are the commonest in Steves' texts. Halliday (2004) explored three different linguistic metafunctions in which language usage creates meaning: The ideational, related to the expression of content; the interpersonal, related to the sender-addressee interaction; and textual, related to internal and external textual cohesion (Francesconi, 2014: 6; Kawase, 2015).

Important period in discourse analysis emerged between the late 1990s and early 2000s with the emergence of CDA - critical discourse analysis as the researchers Teun van Dijk, Ruth Wodak and Norman Fairclough published their work and contributed to this field (Ramanathan and Hoon, 2015: 57). In line with the social theory of discourse, Fairclough (1992) formulated a three-dimensional model in critical discourse analysis which contains text, discursive practice and social practice, and defined textual analysis as the analysis of linguistic features (vocabulary, grammar, cohesion, text structure) and discursive practice. The so called Van Dijk's (1995) theory of ideology is perceived as a multidisciplinary approach which is "the fundamental framework for organizing multiple ideological concepts and consumptions" (Ramanathan and Hoon, 2015: 59), known also as Van Dijk's ideological square. Critical discourse analysis comprises various methods and analyses (Wodak and Meyer, 2009), and can be approached in different ways. Since the article is based on the functionalist view of the language, for the further analysis of texts, Fasold's definition has been considered which says that "the study of discourse is the study of any aspect of language use" (Fasold, 1990: 65). 
Firstly, Rick Steves“ texts about European destinations were examined through content analysis, which is a method used frequently in tourism studies (Botterill and Platenkamp, 2012). It consists of a bundle of techniques for systematic text analysis (Mayring, 2000) and the main themes and ideas of Steves" texts were identified with the help of content analysis. The analysis began with an examination of the general information about Europe's destinations (Austria, Belgium, Bosnia and Herzegovina, Bulgaria, Croatia, Czech Republik, Denmark, England, Estonia, Finland, France, Germany, Greece, Hungary, Ireland, Italy, Montenegro, Netherlands, Norway, Poland, Portugal, Russia, Scotland, Slovakia, Slovenia, Spain, Sweden, Switzerland, Turkey and Wales) on Rick Steves“ website: https://www.ricksteves.com/europe, identifying the situation of text-production, socio-cultural background, the text itself, and the effect of the text. Steves is an established guidebook author and TV host, an expert on travelling around Europe. The linguistic analysis was undertaken further on in the research, exploring repeating discursive patterns, lexical choices and phraseology.

\section{CORPUS ANALYSIS}

The internet is a rich source of available data for linguistic research, offering research materials that are original, authentic, up-to-date and topical. A travelogue, which is "a speech, movie, or piece of writing about someone's experiences while traveling" (http:// www.merriam-webster.com/dictionary/travelogue), shares these characteristics, and is considered one of the significant tools in branding tourism destinations since it is easily accessed on the website, and created to both attract and inform potential tourists. "Informing", "persuading" and "reminding" are the main goals of promotional materials, according to Holloway (2004: 265), and Kannan and Tyagi (2013: 3) state that promotional texts, among others, are "aimed at promoting and selling not only tangible and physical goods, but also ideas and services". Consequently, in promotional texts, the AIDA model (AIDA stands for Attention, Interest, Desire, Action) is used commonly (Gabriel et al., 2006: 505), and it is also very common in the tourism discourse - in texts promoting destinations and attractions, because it is fundamental that promotional materials in tourism meet the traditional and new, modern, contemporary requirements of the advertising discourse. It could well be claimed that Steves' travelogues about European destinations are built on this traditional model. Firstly, Steves tries to get the attention of the potential tourists deciding on their next destination; secondly, the potential tourists need to become interested in the text on the website to read Steves' information on the website further; thirdly, the potential tourists feel the desire actually to visit the destination in Europe and, finally - Action - tourists actually visit one or more European destinations because they have been convinced by Steves' representations of them. In the final stage, they turn from potential tourists into actual tourists. The objective of this article is not to establish the number of tourists who actually visit some European destination due to the persuasive texts by Steves, but it can be assumed, according to Travel discussion Forum Posts on Steves' website (https://search.ricksteves.com/?date_range=6mandfilter=Travel+ Forumand query), that quite a few potential tourists turn into actual tourists visiting a destination in Europe after reading the travelogues. 


\subsection{Positive representation of destinations}

In recent years, linguistic studies of tourism discourse have been on the rise. Jaworska (2016: 83) states that often, research, concerned with representations of destinations in tourism discourse points to the prevalence of stereotypical images. Such (stereotypical), similar or different representations of destinations are achieved through various linguistic devices and techniques. Therefore, linguistic analysis is also in the forefront of this research. The objective of this analysis is to examine linguistic devices used in promotion of tourism destinations. However, Dann's (1996: 68) four sociological models for promotional texts in tourism need to be mentioned. Dann (ibid.) arranged them into four categories as follows: 1) The language of authentication (promotes the experience of the traveller as authentic, genuine, pure, opposing it to the banality of everyday life); 2) The language of differentiation (highlights the contrast between holiday and normal life); 3) The language of recreation (emphasises the recreational and hedonistic side of tourism); and 4)The language of appropriation (tries to adopt an attitude of control and domination of what is unknown).

In his website promotional texts, Steves uses all of Dann's models, but most often the model of authentication, which promises some genuine experience, using adjectives remarkable, beautiful, unique, welcoming, captivating, fascinating, vibrant etc. (the so called adjectivization is employed). Some examples:

(1) Bosnia-Herzegovina has long been — and remains - a remarkable place, with ruggedly beautiful terrain, a unique mix of cultures and faiths, kind and welcoming people who pride themselves on their hospitality, and some of the most captivating sightseeing in southeastern Europe. (https://www.ricksteves.com/europe/bosnia-herzegovina)

(2) Finland is a fun, fascinating, sadly overlooked corner of Europe. Its small population fills a sprawling, rocky, forested land that shares a long border with Russia. (https:// www.ricksteves.com/europe/finland)

With his vivid, and often exaggerated descriptions, which go into extreme comparisons, similes, and modified nouns, Steves tries to persuade the potential tourists of the authentic experience waiting for them. The following description of Spain also employs a "grandpa" simile ("Like a grandpa bouncing a baby on his knee") and contrasts ("ols and new", "modern and traditional"):

(3) Like a grandpa bouncing a baby on his knee, Spain is a mix of old and new, modern and traditional. For the tourist, Spain means bullfights, massive cathedrals, world-class art, Muslim palaces, vibrant folk life, whitewashed villages, and bright sunshine. (https:// www.ricksteves.com/europe/spain)

Pre-trip tourism promotion texts act primarily as motivations for travel, such as the need for serenity, style, fun, or adventure (Francesconi, 2014: 24). According to MacCannel (1989: 14), "the rhetoric of tourism is full of the manifestation of the importance of authenticity of the relationship between the tourists and what they see: This is a typical native house; this is the very place that the leader fell; this is the actual pen used to sign the law; this is the original manuscript; this is the authentic Tlingit Fish Club; this is a real piece of the true Crowns of Thorns." Jaworska (2017: 161) examined figurative speech in 
tourism promotional discourse, and confirmed that metaphorical expressions used in promotional texts about destinations generate sensory fusions that appeal to multiple senses.

Another positive representation of some European destination in Steves' descriptions is achieved by referring to world famous destinations, as in the description of Croatia's towns in the example below, where Steves compares Kvarner Gulf and Istrian Peninsula to Venice by using the adjective "Venetian-flavoured":

(4) Sunny beaches, succulent seafood, and a taste of la dolce vita...in Eastern Europe? With thousands of miles of seafront and more than a thousand islands, Croatia's coastline is Eastern Europe's Riviera. Holiday-makers love its pebbly beaches, predictably balmy summer weather, and dramatic mountains. But there's history here as well: from ruined Roman arenas and Byzantine mosaics to Venetian bell towers, Habsburg villas, and even communist concrete, past rulers have left their mark. Most travelers flock to the Dalmatian Coast, where dramatic cliffs rise from the deep and islands are scattered just offshore. But savvy travelers make time for more: the Venetian-flavored Kvarner Gulf and Istrian Peninsula, the stunning waterfalls of Plitvice Lakes, and Zagreb, the nation's engaging capital.

Cook (1994: 11) used the term "schemata" for "mental representations of typical instances". So, in tourism texts, references to world famous destinations are used to trigger the potential tourist's "schemata" which were created through previous media representations or personal experience. Thus, the positive impression is reinforced. After reading the description of a certain destination, a new schemata with a positive image is created. Italian expression "la dolce vita", meaning "sweet life", is used for the very same reason. Potential tourists have a lot of positive impressions about Italy from songs, films, traditional and new media, and due to that the stereotypical phrase "la dolce vita" is a very useful and often used trigger.

\subsection{Syntactic features of analysed texts}

Lexical density is one of the characteristics of tourism discourse (Manca, 2016), which further on directly influences the syntactic features of tourism promotional texts. As far as the complexity of sentences of Steves " promotional texts about European destinations is concerned, simple sentences are used interchangeably with complex sentences (coordinated and subordinated, among the latter relative clauses, if-clauses, and concessive clauses). Examples of using various types of coordinated and subordinated sentences interchangeably are the following descriptions of Scotland and the Netherlands:

(5) Rugged, colorful, and feisty, Scotland stands apart. From its stony architecture to its unmanicured landscape to the more laid-back nature of its people - and their peculiar fondness for haggis - Scotland is distinctly not England. A proud identity unites the sparsely populated country, all the way from the southern lowlands, which border England just north of Hadrian's Wall, up to the Norwegian latitudes of the rocky Highlands and remote islands. Outside its main cities, Scotland's sights are subtle, but the misty glens, brooding countryside castles, and warm culture are plenty engaging. It's easy to fall in love with the irrepressible spirit and beautiful landscape of this faraway corner of Britain. (https://www.ricksteves.com/europe/scotland) 
(6) Rattling your bike over cobbles, past a line of gabled houses reflected in a mirrorsmooth canal...Holland's just like you imagined it. In the Netherlands' 17th-century Golden Age, Dutch traders established a global economy - and funded a culturally rich society back home. Tiny Holland may just have the world's densest concentration of great artists, and shows off their works in several world-class museums. Be sure to venture beyond Amsterdam - take advantage of the efficient train network, which puts nearly every Dutch destination within an easy day trip. Rent a bike and cruise the flat countryside. Wherever you roam, look behind its placid exterior, where you'll find a complex mix of modern technology, honored traditions, quaint countryside, outrageous architecture, and no-nonsense, globally minded people. (https://www.ricksteves.com/europe/netherlands)

The analysis of Steves' descriptions confirmed Gotti's $(2003,28)$ finding that “compact syntactic structures" are one of the main characteristics of specialised discourses, however, Steves' texts do not display simplistic structures, as might be assumed, and is often the case in promotional texts and specialised discourses. On the contrary, Steves employs complex sentences, modified adjectival and nominal phrases, superlatives, etc., thus, his style could be marked as dense and loquacious, incorporating complex syntactic features.

In the analysed corpus of Steves' texts, the present tenses are used with top priority, the commonest being the present simple tense, and present perfect tense. Some examples of the present simple usage indicating facts that are not debatable, but true:

(7) Austria is content to bask in its good living and elegant, opulent past as the former head of one of Europe's grandest empires. (https://www.ricksteves.com/europe/austria)

(8) Belgium's town squares bristle with soaring spires and warm-brick gables. (https:// www.ricksteves.com/europe/belgium)

(9) From Copenhagen to tiny ship-in-bottle islands, the Danish landscape is equally mellow, with rolling hills, thatched-roof farmhouses, beech forests, and whitewashed churches with stairstep gables...and none of it more than 30 miles from the sea. (https:// www.ricksteves.com/europe/denmark)

(10) France is Europe's most diverse, tasty, and, in many ways, most exciting country to explore. (https://www.ricksteves.com/europe/france)

(11) Barcelona bubbles with life in its narrow Barri Gòtic alleys, along the pedestrian boulevard called the Ramblas, in the funky bohemian quarter of El Born, and throughout the chic, grid-planned part of town called the Eixample. (https://www.ricksteves.com/ europe/spain/barcelona)

(12) Little, mountainous, efficient Switzerland is one of Europe's most appealing destinations. (https://www.ricksteves.com/europe/switzerland)

In accordance with the grammatical rules of the English language it is expected and quite natural that the present simple tense is used most often because promotional texts need to be communicative and easy to understand. The following are some of the examples of descriptions of destinations by using the present perfect tense - usually indicating change over time at the destination or some accomplishment at a destination:

(13) Chamonix's purpose in life has always been to dazzle visitors with some of Europe's top alpine thrills. (https://www.ricksteves.com/europe/france/chamonix)

(14) Apart from the tragic way it separated from Yugoslavia, Bosnia-Herzegovina has long been - and remains - a remarkable place, with ruggedly beautiful terrain, a unique 
mix of cultures and faiths, kind and welcoming people who pride themselves on their hospitality, and some of the most captivating sightseeing in southeastern Europe. (https:// www.ricksteves.com/europe/bosnia-herzegovina)

(15) Since independence in 1991, its Old Town has been scrubbed into a pristine Old World theme park - a fascinating package of pleasing towers, ramparts, facades, striptiis bars, churches, shops, and people-watching. (https://www.ricksteves.com/europe/estonia/ tallinn)

(16) While this predominantly Catholic-Nationalist city has been much contested throughout the Troubles, the conflict is only one dimension of Derry; this pivotal city has a more diverse history and a prettier setting than Belfast. From a leafy monastic hamlet to a Viking-pillaged port, from a cannonball-battered siege survivor to an Industrial Revolution sweatshop, from an essential WWII naval base to a wrenching flashpoint of sectarian Troubles...Derry has seen it all. (https://www.ricksteves.com/europe/ireland/derry)

(17) Its imperial palaces, jewels, and grand boulevards constantly remind visitors that Munich has long been a political and cultural powerhouse. (https://www.ricksteves.com/ europe/germany/munich)

Quite often, Steves uses the future simple tense, and "will", by which he is indicating certainty (perhaps even a promise between the lines) of what awaits tourists at a certain destination:

(18) Yes, you'll have good opportunities for enjoyable wine-tasting, but there is also a soul to this area...if you take the time to look and to listen. (https://www.ricksteves.com/ europe/france/cotes-du-rhone)

(19) Tucked into a far corner of the Continent, Portugal preserves a traditional culture of widows in black and fishermen mending nets. But along with the old, you'll also find the modern, especially in the culturally rich capital of Lisbon and the second city of Porto. (https://www.ricksteves.com/europe/portugal)

(20) If you're looking for quintessential French culture, you'll find it in Burgundy. (https://www.ricksteves.com/europe/france/burgundy)

(21) In Zagreb, you'll find a nearly Prague-like Old World streetscape, a thriving café culture, my favorite urban people-watching in Croatia, the nation's best museums, and virtually no tourists. (https://www.ricksteves.com/europe/croatia/zagreb)

Since the main functions of Steves' texts are promotional, informative, and instructive (descriptive and directive text types), it is not surprising that the present tenses indicating facts and truths are used most frequently. For expressing a high degree of certainty, the future simple tense is used. When some background information is explained, the past tense is adopted (narrative text type). As far as the voice is concerned, the analysis shows that Steves prefers to use the active voice instead of the passive in his texts. By using the active voice, Steves achieves that his texts are more communicative, more subjective and, consequently, more convincing.

A significant characteristic of tourism texts is modality. According to Maci (2012: 49), modality can be classified as:

- Epistemic, when expressing the speaker's degree of commitment to the truth proposition; 
- Deontic, when expressing the speaker's responsibility/authority in giving permission, imposing commands, offering suggestions;

- Dynamic, when expressing the speaker's/listener's ability or disposition.

In Steves' descriptions, epistemic modality prevails, that is the modality which is, according to Nuyts (2000: 21), "an evaluation of the chances that a certain hypothetical state of affairs under consideration (or some aspect of it) will occur, is occurring, or has occurred in a possible world which serves as the universe of interpretation for the evaluation process, and which, in the default case, is the real world (or rather, the evaluator's interpretation of it). In Steves' texts, very often, the modal "should" is replaced by the usage imperatives, which, according to Biber et al. (2002: 256) "urge the addressee to do something (or not to do something)". Some examples of imperatives follow:

(22) Peruse the city's world-class museums, then pedal along the Spree riverfront before sitting down to nurse a stein of brew or dive into a cheap Currywurst. (https:// www.ricksteves.com/europe/germany/berlin)

(23) Take it all in, then pause to watch the clouds blow past stately old gables - and see the Golden Age reflected in a quiet canal. (https://www.ricksteves.com/europe/netherlands/amsterdam)

(24) Come to Cassis to dine portside, swim in the glimmering-clear water, and explore its rocky inlets. (https://www.ricksteves.com/europe/france/cassis)

(25) Take a trip back in time at Skansen, Europe's first and best open-air folk museum. (https://www.ricksteves.com/europe/sweden/stockholm)

Another example of epistemic modality using the modal verb may:

(26) You may associate Gdańsk with dreary images of striking dockworkers from the nightly news in the 1980 s - but there's so much more to this city than shipyards, Solidarity, and smog. (https://www.ricksteves.com/europe/poland/gdansk )

\subsection{Lexical and textual features of Steves' texts}

Travelogues, and Steves' are no exception to the rule, feature special style and register. Steves employs evaluative and emotive register - his website texts are emotional, even euphoric, some nostalgic, and some charismatic. Cappelli (2006: 295) pointed out that travelogues "deal with traveller's expectations", and that they often feature evaluative and subjective expressions. Because some tourists like to squeeze many activities into one day, enumerating the activities that can be carried out in a single day has become a pattern, which Steve does not avoid - also with the objective to persuade and attract as many potential tourists as possible:

(27) As you explore Italy, you'll stand face-to-face with some of the world's most iconic images from this 2,000-year history: the Colosseum of Ancient Rome, the medieval Leaning Tower of Pisa, Michelangelo's David and Botticelli's Venus, the playful Baroque exuberance of the Trevi Fountain... and the elegant decay that surrounds the canals of Venice. (https://www.ricksteves.com/europe/italy)

In his texts, Steves does not neglect the verbal imagery. In the example below the verb to inhale is used metaphorically: 
(28) As I walked out of my hotel in Vienna on Sunday morning, I realized I was in a city with a rich culture you can almost inhale, and a vivid history you can almost touch. (http://blog.ricksteves.com/blog/sunday-morning-vienna-style/)

According to Dann (1996), the lexical choices of the text are fundamental. By using the words magic, ideal, magnificent, etc., Steves triggers the associations to the fantasy world and fairy tales indicating that, at a certain destination, fairy tales can come true. Consequently, the destination becomes more attractive and desirable to the potential tourist:

(29) Sevilla also has its share of impressive sights - but the real magic is the city itself, with its tangled former Jewish Quarter, riveting flamenco shows, thriving bars, and teeming evening paseo. (https://www.ricksteves.com/europe/spain/sevilla)

(30) The magic of Prague, the beauty of Český Krumlov, and the lyrical quality of the countryside relieve the heaviness caused by the turmoil that passed through here. Get beyond Prague and explore the country's medieval towns. (https://www.ricksteves.com/ europe/czech-republic)

As seen from the example above, by using carefully selected adjectives (keywords), the destination can be represented as magical, beautiful, lyrical, romantic, adventurous, fun, wild, unspoiled, exotic, etc. Depending on what the author of the text tries to emphasise, various registers may be employed (register of nostalgia, register of health, register of food and drink, eco-tourism, etc.). Cohen (1985) describes the vocabulary technique of employing "dramaturgic effects" the "keying" (Cappelli, 2006: 331). By using keywords efficiently (adjectives, adjective-noun collocations, verbs, etc.) that are appealing to tourists, readers really become tourists, as Cappelli's (2006) title of the book How the English language makes tourists out of readers suggests. Tourism promotion texts employ certain phrases, collocations, and patterns, which can even turn into tourism clichés if they are used too often. One of such commonly used phrases is it's easy to fall in love with, which Steve also uses in his descriptions of European destinations:

(31) It's easy to fall in love with the irrepressible spirit and beautiful landscape of this faraway corner of Britain. (https://www.ricksteves.com/europe/scotland)

As the example above shows, Steves employs metaphorical and poetic language in order to picture romanticism, happiness, and beauty. Among them, there is a great number of epithets, also modified (for example castle-topped) which are an outstanding device due to the fact that they characterize a destination significantly. Examples:

(32) Germany, Austria, and Switzerland are blessed with some of Europe's most high-powered sights. There's spectacular scenery - the jagged Alps, rolling hills of forests and farms, flower-filled meadows, and mighty rivers - dotted all over with castles and churches of every variety. And for the senses...wander through a town and enjoy strudel at the bakery or sip a stein of beer while men in lederhosen play oompah music. (https://www.ricksteves.com/tours/tour-news/may-2016/five-tastes-of-germanyaustria-switzerland)

(33) Sintra is a mix of natural and man-made beauty: fantasy castles set amid exotic tropical plants, lush green valleys, and craggy hilltops with hazy views of the Atlantic and Lisbon. It was the summer escape of Portugal's kings, and those with money and a desire to be close to royalty built their palaces amid luxuriant gardens in the same neighborhood. 
Lord Byron called this bundle of royal fancies and aristocratic dreams a "glorious Eden," and even though it's mobbed with tourists today, it's still magnificent. With extra time, explore the rugged and picturesque westernmost tip of Portugal at nearby Cabo da Roca. (https://www.ricksteves.com/europe/portugal/sintra)

(34) A decade ago, the city center was grim, deserted, and dangerous - a place where only thieves and fools dared to tread. Today it's downright charming, bursting with colorfully restored facades, lively outdoor cafés, swanky boutiques, and in-love-with-life locals. (https://www.ricksteves.com/europe/slovakia/bratislava)

(35) Idyllic Istria, the wedge-shaped peninsula at Croatia's northwest corner, reveals itself to you gradually and seductively. Pungent truffles, Roman ruins, striking hill towns, quaint coastal villages, carefully cultivated food and wine, and breezy Italian culture all compete for your attention. (https://www.ricksteves.com/europe/croatia/istria)

Blažević and Stojić (2006: 60) emphasised that in tourism promotion texts "[k]ey words refer not only to the attributes of the destination but also to the requirements of the potential tourist".

Among stylistic devices adopted by Steves, contradictions and binary oppositions are among those used most commonly:

(36) Naples is Italy in the extreme - its best (birthplace of pizza and Sophia Loren) and its worst (home of the Camorra, Naples“ „family“ of organized crime). The city has a brash and vibrant street life — „Italy in your face“ in ways both good and bad. Even though it's Italy's grittiest, most polluted, and most crime-ridden city, walking through its colorful old town is one of my favorite experiences anywhere in Europe. (https://www. ricksteves.com/europe/italy/naples)

In Steves' website descriptions, examples of trilogistic structures can also be found, which are effective attention keepers (Davidson, 2003: 61):

(37) Enigmatic. Intimidating. Fascinating. (https://www.ricksteves.com/europe/russia)

Also similes (comparing two things by using like or as) and comparisons are an outstanding feature of Steves' texts:

(38) Mont St-Michel, one of the top pilgrimage sites of Christendom through the ages, floats like a mirage on the horizon. (https://www.ricksteves.com/europe/france/mont-stmichel)

(39) These rugged woods and hilltop castles will make you feel as if you're walking through the garden of your childhood dreams. (https://www.ricksteves.com/europe/ czech-republic)

Steves texts are rich in superlatives, amplifications, and hyperboles (exaggerations):

(40) Norway is stacked with superlatives - it's the most mountainous, most scenic, and most prosperous of all the Scandinavian countries. Perhaps above all, Norway is a land of intense natural beauty, its famously steep mountains and deep fjords carved out and shaped by an ancient ice age. (https://www.ricksteves.com/europe/norway)

(41) France is Europe's most diverse, tasty, and, in many ways, most exciting country to explore. (https://www.ricksteves.com/europe/france)

(42) Kraków is easily Poland's best destination ... (https://www.ricksteves.com/ europe/poland/krakow) 
Among the devices that Steves often employs are enumerations and repetitions:

(43) Bustling university life, thought-provoking museums, breathtaking churches, great restaurants, sprawling parks, and vivid Jewish heritage sights round out the city's appeal. Of all of the Eastern European cities laying claim to the boast ,the next Prague “" Kraków is for real. (https://www.ricksteves.com/europe/poland/krakow)

(44) From funky urban neighbourhoods to tranquil convents, from old-fashioned lace to high-powered European politics, little Belgium delights. (https://www.ricksteves.com/ europe/belgium)

These figures of speech and stylistic devices make Steves' texts more vivid, interesting, poetic, romantic, and they also function as the mechanisms for keeping the attention of the reader.

A significant and outstanding characteristic of Steves' website descriptions of European destinations, is languaging, which is related to acquiring a linguistic sense of a destination and positioning oneself within the repertory of customary practices of a local culture (Cappelli, 2013). Steves uses this verbal technique and inserts words of destinations' languages into English, i. e.: kava, sardana, Bell'Italia!, gelato, pączek, Wiener Schnitzel, etc. Some examples of languaging:

(45) Stroll down revitalized boulevards that evoke the city's glory days, pausing at an outdoor café to sip coffee and nibble at a paczek (jelly doughnut). (https://www.ricksteves. com/europe/poland/warsaw)

(46) From the stirring sardana dance in Barcelona to the sizzling rat-a-tat-tat of flamenco in Sevilla, this country creates its own beat amid the heat. (https://www.ricksteves. com/europe/spain)

(47) But where else can you stroll the same pedestrian streets walked by Michelangelo, Leonardo, and Botticelli while savoring the world's best gelato? (https://www.ricksteves. com/europe/italy/florence)

(48) Bell'Italia! Italy has Europe's richest, craziest culture. (https://www.ricksteves. com/europe/italy)

As the examples above show, employing the languaging technique and using foreign words in a text provides the sense of local to the reader - probably with an additional goal to impress the reader as well. This supports Dann's (1996: 184) view of languaging, which he describes also as "the impressive use of foreign words". Thus, languaging contributes to authenticity of destinations presented in Steves' texts, and according to Cappelli (2013), reduces the cultural distance between two cultures.

\section{DISCUSSION}

Rick Steves' travelogues are carefully structured and thus informative within limited space. In addition, they display a selection of lexical, structural and grammatical choices and writing techniques that are never neutral, but always trying to influence, persuade, attract and seduce the potential tourist to become an actual tourist arriving to the destination. By focusing on positive characteristics and by employing exaggeration along with other mentioned techniques, the analysed texts impact directly the promotion of described destinations. They are, consequently, also examples of Buourdieu's theory 
on how language as a significant tool of persuasion is attracting tourists and businesses and, consequently, making profits by producing "profit of distinction on the occasion of each social exchange « (Bourdieu, 1991: 55). Communication acts, however, receive their value only in their relation to the market. As it was decided to conduct the research based on the website texts by Rick Steves, it should be pointed out that, the fact that only texts from one source have been analysed, presents the limitations of this analysis. But despite the limitations, the study provides us with classic examples of promotion tourism discourse and promotion tourism language, and represents good foundations for further studies about the features of language used for tourism promotional purposes. This analysis shows that linguistic patterns and the choice of lexical items in Steves' descriptions of European destinations support Dann's (1996: 65) argument that the language of tourism discourse uses "positive and glowing terms" to describe "the services and attractions it seeks to promote" (ibid.). Sometimes, Steves uses similar phrases for different destinations, so in his website texts sometimes these patterns repeat and turn into clichés, perhaps even formulas of tourism discourse. Mainly, the descriptive and directive texts are dense, focused on specific tourism registers, full of modified nouns, adjectives, superlatives and expressions of extreme, supported by adverbial, participial, and verbal imagery. All lexical items in the descriptions that have the objective to be appealing to tourists are chosen carefully. Often Steves tries to establish the magical framework of the destination by employing the "magic technique" and using the words magic, magnificent - words associated with fantasy worlds and fairy tales indicating that, at the destination, fairy tales can come true. The majority of Dann's (1996: 101- 134) tourism categories, which he names as three Rs (Romanticism, Regression, Rebirth), three Hs (Happiness, Hedonism, Helio-centrism), three Fs (Fun, Fantasy, Fairy Tales), and three Ss (Sea, Sex, Socialization) are used in Steves' travelogues - Steves creates them by employing poetic, metaphorical language and by using carefully chosen words. To create an attractive invitation to a destination Steves employs a combination of the aforementioned categories. Using various combinations of categories conveys multiple messages which target many potential tourists, their needs and interests. According to Steves' travelogues European destinations are all desirable destinations trying to address many (if not all) types of interests. This analysis, therefore, supports the assumption that linguistic choices play a significant role in the tourism sector.

\section{CONCLUSION}

Following Dann's (1996) and Cappelli's (2006) models of research and based on linguistic analysis, the present analysis confirmed the significance of lexical choices in tourism. Despite the fact that only texts from one source have been analysed, which presents the limitations of the research, it was confirmed that linguistic patterns and the choice of lexical items in Steves' English descriptions of European destinations play a fundamental role in tourism. In this sense, English, as a lingua franca, still has the monopoly in the world's tourism business. The fact is that tourism texts are very dynamic, evolving, and constantly subject to changes, but at the same time subordinated to various linguistic techniques, patterns and lexical choices. In addition to that, recently, 
for example, the migration to the web of tourism communication has been upgraded with the app communication and social media, thus professionals working in tourism branding, tourism research and tourism education need to keep track of the novelties and adjust their working processes. Efficient promotion can only occur through the efficient use of tourism discourse which addresses the needs of potential tourists who become actual tourists if they are persuaded by the right combinations of linguistic choices. Tourists bring money to destinations, destinations develop and developed destinations attract not only tourists but also businesses. Therefore, it is paramount that the experts in the field of tourism, especially in the field of tourism promotion and branding, are capable of utilising language as a significant tool in the tourism industry - also as a means for earning money, making profits, and as a means of promoting the overall longterm sustainable destination development.

\section{BIBLIOGRAPHY}

ARFIN, M.B.S. et al. (2012): "Language for Tourism: A Review of Literature", The $8^{\text {th }}$ International Language for Specific Purposes (LSP) Seminar - Aligning Theoretical Knowledge with Professional Practice, Procedia - Social and Behavioral Sciences, pp. 136-143. Disponible en http://ac.els-cdn.com/S1877042812052408/1s2.0-S1877042812052408-main.pdf?_tid=c3d1e9f4-96cf-11e7-bf7c-00000aab0f02an dacdnat=1505120654_91b1d492f57b9f1ed826b0f8cf7270fe.

BIBER, D,S.C. and G. LEECH, G. (2002): Longman Student Grammar of Spoken and Written English. Harlow, Essex, Pearson Education Ltd.

BLAŽEVIĆ, N. and STOJIĆ, A. (2006): "Pragmalinguistic elements in tourist destination image formation", Tourism and Hospitality Management, no.1, pp. 57-66.

BOTTERILL, D. and PLATENKAMP, V. (2012): Key concepts in tourism research. Los Angeles, Sage Publications.

BOURDIEU, P. (1991): Language and Symbolic Power. Oxford, Basil Blackwell.

BRYCE, D., MACLAREN, A.C. and O'GORMAN, K.D. (2013): "Historicising hospitality and tourism consumption: orientalist expectations of the Middle East", Consumption, Markets and Culture, no. 1, pp. 45-64.

CALVI, M. V. (2000): Il linguaggio spagnolo del turismo. Viareggio, Baroni Editore.

CAPPELLI, G. (2013): "Travelling words: Languaging in English tourism discourse". Disponible en https://s3.amazonaws.com/academia.edu.documents/33922647/languaging-english-tourism-discourse.pdf?AWSAccessKeyId=AKIAIWOWYYGZ2Y5 3UL3AandExpires=1505112259andSignature=\%2BpQZ3tq8VVaKM5m4qOZQbS5

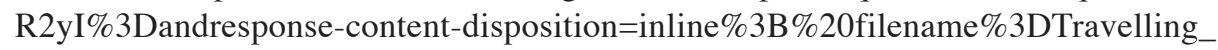
words_Languaging_in_English.pdf

CAPPELli, G. (2006): Sun, Sea, Sex, and the Unspoilt Countryside: How the English Language Makes Tourists Out of Readers. Pari, Pari Publishing.

COOK, G. (1994): Discourse and Literature. Oxford, Oxford University Press.

CRISPIN T. and JAWORSKI A. (2011): "Tourism discourse: Languages and banal globalization", Review of Applied Linguistics, vol. 2, pp. 285-312. 
CUMMING, S, TSUYOSHI, O. and LAURY, R. (2011): "Discourse, Grammar and Interaction", en Discourse Studies: A Multidisciplinary Introduction. London, Sage, $2^{\text {nd }}$ ed., pp. 8-10.

DANN, G.M.S. (1996): The language of Tourism: A Sociolinguistic Perspective. Wallingford, Oxon, CAB International.

DAVIDSON, J. (2003): The Complete Guide to Public Speaking. John Wiley and Sons, Inc., New Jersey.

DIELEMANS, J. (2008): Vaelkommen till paradiset: reportage om turistindustrin. Stockholm, Atlas.

FAIRCLOGH, N. (1992). Discourse and Social Change. Cambridge, Polity press.

FASOLD, R. (1990): Sociolinguistics of Language. Oxford, Basil Blackwell.

FRANCESCONI, S. (2006): Translating Tourism Linguistic / Cultural Representations. Trento, Università degli Studi di Trento.

FRANCESCONI, S. (2014): Reading Tourism Texts: A multimodal analysis. Bristol, Buffalo, Toronto, Channel View Publications.

GABRIEL, H., KOTTSOR, R. and BENNET, R. (2006): “Advertising planning, adagency use of advertising models, and the academic practitioner divide", Marketing Intelligence and Planning, no. 5, pp. 505-527.

GOTTI, M. (2006): “The language of Tourism as Specialized Discourse”, en Translating Tourism. Linguistic/cultural Representations. Trento, Editrice Università degli Studi di Trento, pp. 15-34.

HALL, S. (1997): Representation: Cultural representations and signifying practices. London, Sage.

HALLIDAY, M.A.K. (2004): An Introduction to Functional Grammar, 3rd edition. Arnold, London.

HOLLOWAY, J.C. (2004): Marketing for Tourism. Harlow, Essex, Pearson Education Ltd.

JAWORSKA, S. (2017): "Mataphors We Travel by: A Corpus-Assissted Study of Metaphors in Promotional Tourism Discourse", Metaphor and Symbol, vol. 32, n 3, pp. 161-177.

JAWORSKA, S. (2016): “A comparative corpus-assisted discourse study of the representations of hosts in promotional tourism discourse", Corpora, vol. 11, no 1, pp. 83-111.

JAWORSKI, A. and PRITCHARD, A. (Ed.) (2005): Discourse, Communication and Tourism. Clevedon, Cromwell Press.

JAWORSKI, A. and THURLOW, C. (2015): Tourism Discourse. The International Encyclopedia of Language and Social Interaction, pp. 1-6.

KANNAN, R. and TYAGI, S. (2013): "Use of Language in Advertisements", English for Specific Purposes World, pp, 1-10. Disponible en http://www.esp-world.info/Articles_37/Kannan_Use_of_Language_in_Advertisements.pdf

KAWASE, T. (2015): "Metadiscourse in the Introductions of PhD theses and researches", Journal of English for Academic Purposes, vol. 20, pp, 114-124.

LUO, Q. and ZHONG, D. (2015): "Using social network analysis to explain communication characteristics of travel-related electronic word-of-mouth on social networking sites", Tourism Management, vol. 46, pp. 274-282. 
MACI, S. (2012): “Tourism as a specialised discourse: The case of normative guidelines in the European Union", Token: A Journal of English Linguistics, Jan Kochanowski University Press. Disponible en http://www.ujk.edu.pl/token/wp-content/uploads/2013/01/ Token_2012_S_Maci.pdf

MACCANNEL, D. (1989): The Tourist: A New Theory of the Leisure Class. New York, Schocken Books.

MANCA, E. (2016): Persuasion in Tourism Discourse: Methodologies and Models. Newcastle upon Tyne, Cambridge Scholars Publishing.

MAYRING, P. (2000): "Qualitative Content Analysis [28 paragraphs]", Forum Qualitative Sozialforschung / Forum: Qualitative Social Research, no. 2, Art. 20, Disponible en http://nbn-resolving.de/urn:nbn:de:0114-fqs0002204

MERRIAM-WEBSTER ONLINE DICTIONARY. Disponible en http://www.merriamwebster.com/dictionary/travelogue

MOSCARDO, G. (1999): Making visitors mindful: principles for creating quality sustainable visitor experiences through effective communication. Champaign, Sagamore.

NARANGAJAVANA, Y., CALLARISA FIOL, L. J., ANGEL MOLINER TENA, M., RODRIGUEZ ARTOLA, R. M. and SANZHEZ GARCIA, J. (2017): "The influence of social media in creating expectations. An empirical study for a tourist destination", Annals of Tourism Research, vol. 65, pp. 60-70.

NELSON, V. (2014): "Representations of a destination brand in online tourism information sources: The case of Slovenia", Tourism, Culture and Communication, Vol. 14, $\mathrm{n}^{\mathrm{o}} 1$, pp. 41-52.

NUYTS, J. (2000): Epistemic Modality, Language, and Conceptualization: A CognitivePragmatic Perspective. Amsterdam, Philadelphia, John Benjamins Publishing Company.

RAMANATHAN, R. and HOON, B.T. (2015): “Application of Critical Discourse Analysis in Media Discourse Studies", 3L: The Southeast Asian Journal of English Language Studies, col. 21, n ${ }^{\circ} 3$, pp. 57-68.

REDONDO-CARRETERO, M., CAMARERO-IZQUIERDO, C., GUTIERREZARRANZ, A. and RODRIGUEZ-PINTO, J. (2017): "Language tourism destinations: a case study of motivations, perceived value and tourists' expenditure", Journal of Cultural Economics, vol. 41, n 2, pp. 155-172.

RICK STEVES' TRAVELOGUES about European destinations, retrieved from /disponible en https://www.ricksteves.com/europe

SAID, E. W. (1991): Orientalism: Western Conceptions of the Orient. London, Penguin Books.

SALAZAR, N.B. (2006): "Touristifying Tanzania: Local Guides, Global Discourse", Annals of Tourism Research, vol. 33, n 3, pp. 833-852.

SWALES, J. (1990): Genre Analysis: English in Academic and Research Settings. Cambridge, Cambridge Applied Linguistics.

THITTHONGKAM, T. and WALSH, J. (2010): "Roles of Language in Tourism Organisational Management", Asian Journal of Management Research, disponible en http:// www.ipublishing.co.in/ajmrvol1no1/EIJMRS1016.pdf 
THURLOW, C., JAWORSKI, A. (2010): Tourism Discourse: Language and Global Mobility. Australia, Palgrave Macmillan.

URRY, J. (2002): The tourist gaze. London, Thousand Oaks, New Delhi, Sage Publications.

VAN DIJK, T.A. (1992): "Discourse analysis as ideology analysis", en Language and Peace. New York, London, Routledge, pp. 47-142.

WODAK, R. and MEYER, M. (2009): "Critical discourse studies: A sociocognitive approach", en Methods of critical discourse analysis. Thousand Oaks, Sage, pp. 62-86. 